\title{
Syntymäpainon vaikutus porsaiden menestymiseen teurastukseen saakka
}

\author{
Kirsi Partanen ${ }^{1)}$, Marja-Liisa Sevón-Aimonen ${ }^{2)}$, Markku Honkavaara ${ }^{3)}$ ja Heikki Hassinen ${ }^{4)}$ \\ ${ }^{1)}$ MTT, Kotieläintuotannon tutkimus, Tervamäentie 179, 05840 Hyvinkää, kirsi.partanen@mtt.fi \\ ${ }^{2)}$ MTT, Biotekniikka- ja elintarviketutkimus, 31600 Jokioinen, marja-liisa.sevon-aimonen@mtt.fi \\ ${ }^{3)}$ Lihateollisuuden tutkimuskeskus, PL 56, 13101 Hämeenlinna, markku.honkavaara@ltk.fi \\ ${ }^{4)}$ Finnpig Oy, PL 117, 60101 Seinäjoki, heikki.hassinen@finnpig.fi
}

\section{Tiivistelmä}

Emakon pahnuekoko vaihtelee suuresti, ja pahnuekoon kasvaessa myös kuolleena syntyneiden porsaiden lukumäärä kasvaa. Suurin osa elävänä syntyneiden porsaiden kuolemista tapahtuu ensimmäisten elinpäivien aikana. Pieni syntymäpaino ja heikko elinvoima lisäävät porsaan riskiä menehtyä ensimmäisten elinpäivien aikana joko emakon ruhjomana tai nälkiintymisen ja kylmettymisen seurauksena. Toisaalta pienikin porsas voi kasvaa normaalisti teurastukseen saakka, mutta isompana syntyneitä hitaammin. Tämän tutkimuksen tavoitteena oli selvittää, miten pahnuekoko vaikuttaa porsaan syntymäpainoon ja sen hajontaan, ja mikä on syntymäpainon merkitys porsaan selviytymisen, kasvun ja teuraslaadun kannalta.

Aineistona oli 59 norjanmaatiasrodun ensikkoa, jotka oli siemennetty duroc-karjuilla. Pahnueisiin syntyi yhteensä 665 porsasta, joista 45 syntyi kuolleena. Pahnueisiin syntyi keskimäärin 11,5 porsasta, joista 10,5 elävänä. Pahnueen porsaiden keskimääräinen syntymäpaino pieneni 45 g ja pahnueen pienimmän porsaan paino $81 \mathrm{~g}$ pahnuekoon kasvaessa porsaalla. Samalla myös syntymäpainojen variaatiokerroin suureni. Porsaan syntymäpainon ja kasvunopeuden välillä oli positiivinen korrelaatio. Syntymäpainon ja kasvun välinen yhteys on luonnollisesti suurin, kun porsaan ravinnon saanti on emakon tuottaman maidon varassa ( $r=0,45, P<0,001)$. Syntymäpainon ja kasvunopeuden välinen yhteys heikkeni porsaan kasvaessa, mutta vaikutti kuitenkin päiväkasvuun syntymästä teurastukseen saakka $(r=0,35, P<0,001)$.

Pieni syntymäpaino lisäsi porsaan riskiä menehtyä kasvatuksen aikana. Enintään 1 kg painoisina syntyneistä porsaista 37 \% kuoli kasvatusaikana, ja näistä suurin osa jo ennen välitystä. Elävänä syntyneiden porsaiden kuolleisuus pieneni porsaiden syntymäpainon kasvaessa. Porsaan vieroituspaino ja kasvu ennen vieroitusta suurenivat lineaarisesti syntymäpainon kasvaessa. Syntymäpainon lisäksi imevien porsaiden kasvuun ja vieroituspainoon vaikutti emakon imettämien porsaiden lukumäärä. Kasvu hidastui ja vieroituspaino pieneni imetettävien porsaiden lukumäärän kasvaessa. Syntymäpainon ja välikasvatusajan kasvun välillä havaittiin käyräviivainen yhteys, kuten myös kasvussa syntymästä välitykseen. Kun analysointiin otettiin mukaan vain ongelmitta teurastukseen asti kasvaneet siat, emakon imettämien porsaiden lukumäärä vaikutti myös näiden vaiheiden kasvuun. Porsaan syntymäpainolla ei ollut kuitenkaan merkitsevää vaikutusta lihasikojen kasvuun. Sen sijaan syntymän ja teurastuksen välisen päiväkasvun välillä oli positiivinen yhteys ja elinikäinen päiväkasvu suureni lineaarisesti syntymäpainon kasvaessa.

Syntymäpainolla oli käyräviivainen vaikutus sikojen teurastusikään, ja vaikutus oli erilainen tanskalaisen ja norjalaisen duroc-isälinjan jälkeläisissä. Tanskalaisen durocin jälkeläisillä pienimmät syntymäpainot pidensivät teurastusikää voimakkaammin kuin norjalaisen durocin jälkeläisillä Syntymäpaino ei kuitenkaan vaikuttanut merkitsevästi ruhon tai sen osien (kinkku, selkä, kylki, lapa) lihaprosenttiin.

Tulosten perusteella porsaan syntymäpainolla on merkitystä porsaan selviytymisen ja kasvun kannalta. Syntymäpainon vaikutus on suurin imetyksen ja välikasvatuksen aikana, mutta se näkyy myös sikojen kasvunopeudessa syntymästä teurastukseen. Enintään kilon painoisilla porsailla on suurin riski menehtyä kasvatusaikana. Ne myös kasvavat porsasvaiheessa hitaasti ja selviävät harvemmin koko kasvatusajan ongelmitta teurastukseen saakka. Syntymäpaino vaikuttaa porsaiden kasvuun syntymästä välitykseen, muttei enää lihasikojen kasvuun. Pahnue- ja välikasvatusajan hitaammasta kasvusta johtuen siat saavuttavat teuraspainotavoitteen vanhempina. Syntymäpaino ei kuitenkaan vaikuta ruhojen lihakkuuteen.

Asiasanat: porsas, syntymäpaino, kasvu, teuraslaatu 


\section{Johdanto}

Emakon pahnuekoko vaihtelee suuresti, muutamasta jopa 25 porsaaseen. Kuviossa 1 on esitetty esimerkkinä yksittäisellä tilalla vuoden aikana syntyneiden pahnueiden kokojakauma: 78 \%:iin pahnueista oli syntynyt 11 - 18 porsasta ja $9 \%$ :iin yli 18 porsasta. Kaikki porsaat syntyivät elävinä $40 \%$ :ssa pahnueista, ja $31 \%$ :ssa pahnueista oli yksi, 16 \%:ssa kaksi ja $13 \%$ :ssa useampi kuolleena syntynyt porsas. Syntymäkuolleisuus oli keskimäärin 8 \%. Spicer ym. (1986) havaitsi 238 pahnueen aineistosta 8,3 \% syntyneistä porsaista kuolleen ennen syntymää tai porsimisen aikana. Kuolleena syntyneiksi tulee kirjatuksi myös porsaita, jotka kuolevat heti syntymän jälkeen. Glastonbury (1977) tutki 180 porsaan kuolinsyyn, ja näistä $13 \%$ oli kuollut ennen syntymää, 75 \% porsimisen aikana ja 12 \% heti syntymän jälkeen. Emakon porsimisvaikeuksien vuoksi hapen puutteesta kärsivä porsas on heikko ja kuolee heti syntymän jälkeen.

Kuvio 2 havainnollistaa emakon porsimakerran vaikutusta pahnueen kokoon. Pahnuekoko kasvaa yleensä kolmanteen porsimakertaan saakka ja alkaa pienentyä neljännen porsimakerran jälkeen. Toinen pahnue voi olla ensimmäistä pahnuetta pienempikin (Quiniou ym. 2002), jos emakko laihtuu paljon ensimmäisen pahnueen imetyksen aikana (Schenkel ym. 2010). Kuolleena syntyneiden porsaiden lukumäärä kasvaa sekä emakon porsimakertojen lisääntyessä että pahnuekoon kasvaessa (Leenhowers ym. 1999). Pahnuekoon kasvaessa porsaiden keskimääräinen syntymäpaino pienenee, ja syntymäpainojen hajonta kasvaa. Alle 1 kg painoisten porsaiden määrä kasvaa selvästi, kun pahnueeseen syntyy yli 13 porsasta (Quiniou ym. 2002). Syynä pieniin syntymäpainoihin voi olla ahtaus ja sikiöiden ravintoaineiden saannin rajoittuminen kohdussa suuren pahnueen tiineyksissä (Père ym. 1997, Père ja Etienne 2000). Pieni syntymäpaino lisää porsaan riskiä menehtyä ensimmäisten elinpäivien aikana joko emakon ruhjomana tai nälkiintymisen ja kylmettymisen seurauksena. Quinioun ym. (2002) tutkimuksessa enintään 1 kg painoisena syntyneistä porsaista 58 \% selviytyi vieroitukseen saakka, ja alle 600 g painavista vain $15 \%$. Pienet porsaat selviytyvät hengissä ja kasvavat paremmin pienissä kuin suurissa pahnueissa (Deen ja Bilkei 2004).

Syntymäpaino vaikuttaa porsaan hengissä pysymisen lisäksi sen kasvuun myöhemmissä tuotantovaiheissa. Porsaiden päiväkasvu on sekä pahnueaikana että välikasvatuksessa sitä nopeampaa, mitä suurempikokoisena porsaat syntyvät (Quinioun ym. 2002, 2004). Syntymäpaino vaikuttaa lihasikojenkin kasvuun, muttei yhtä voimakkaasti kuin porsaiden kasvuun (Quinioun ym. 2004, Fix ym. 2010a). Pienenä syntyneet porsaat syövät rehua vähemmän ja kasvavat sen vuoksi isompiaan hitaammin, mutta rehuhyötysuhteeseen syntymäpainon ole todettu vaikuttavan (Quinioun ym. 2004). Fix’n ym. (2010b) mukaan syntymäpaino vaikuttaa myös välitysporsaiden ja teurastettavien sikojen laatuun. Porsaan syntymäpainon kasvaessa kasvunopeus parani kaikissa myöhemmissä tuotantovaiheissa (Fix ym. 2010a). Keskimääräistä pienempi syntymäpaino pienentää voimakkaasti todennäköisyyttä sille, että siat kuuluvat lihasikalaan siirrettäessä ja teuraaksi lähetettäessä parhaaseen laatuluokkaan.

Tämän tutkimuksen tavoitteena oli selvittää hyvän porsastuotoksen omaavien norjanmaatiaisemakoiden ensipahnueista, miten pahnuekoko vaikuttaa porsaan syntymäpainoon ja sen hajontaan, ja miten syntymäpaino vaikuttaa porsaan selviytymisen ja kasvuun syntymästä teurastukseen saakka sekä ruhojen lihakkuuteen ja tilityshintaan.

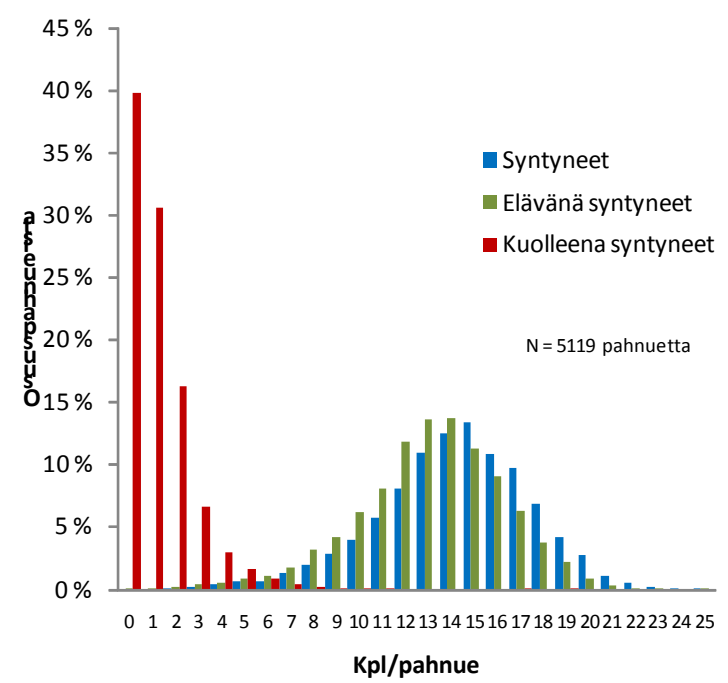

Kuvio 1. Pahnueiden kokojakauma.

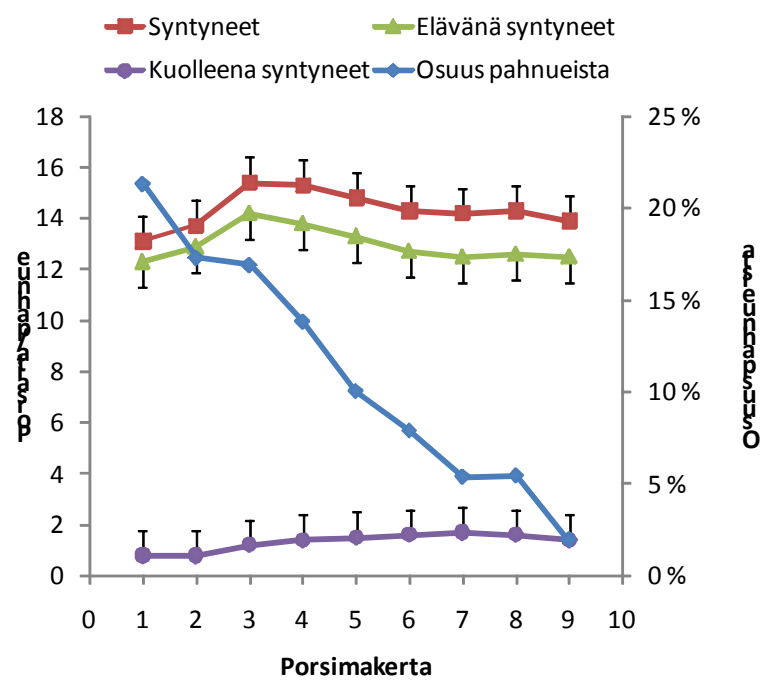

Kuvio 2. Pahnuekoko eri porsimakerroilla. 


\section{Aineisto ja menetelmät}

Aineistona oli 59 norjanmaatiaisemakon ensipahnuetta, jotka syntyivät kolmessa ryhmässä: lokakuussa ja joulukuussa 2009 ja maaliskuussa 2010. Näissä ryhmissä emakot porsivat 5 - 6 päivän sisällä. Pahnueiden isät olivat norjalaisen ja tanskalaisen duroc-rodun karjuja. Pahnueisiin syntyi yhteensä 665 porsasta, joista 45 syntyi kuolleena tai oli kuollut välittömästi syntymän jälkeen. Pahnueissa oli keskimäärin 11,3 \pm 4,2 porsasta, joista keskimäärin 10,5 \pm 4,1 syntyi elävänä. Syntyneet porsaat kasvatettiin duroc-isälinjojen vertailua varten, ja tässä aineistoa käytettiin porsaan syntymäpainon vaikutusten tutkimiseen.

Porsaat punnittiin yksilöllisesti $48 \mathrm{~h}$ kuluessa syntymästä ja ne saivat yksilölliset korvanumerot. Pahnueita tasattiin tarpeen mukaan. Porsaat punnittiin vieroitettaessa (vieroitus $27,8 \pm 1,7 \mathrm{pv}$ iässä). Välikasvattamossa pahnueet sekoitettiin ja porsaita kasvatettiin 20 sian karsinoissa. Porsaat punnittiin päivää ennen siirtoa lihasikalaan, minne koko erä siirrettiin kerralla (siirto 72,2 $\pm 3,3$ pv iässä). Porsaat ruokittiin Suomen Rehu Oy:n rakeistetuilla täysrehuilla. Pikku-Pekoni -täysrehua (1,14 ry/kg ja 11,8 g/ry sulavaa lysiiniä) annettiin noin 10 päivän iästä lähtien. Viiden päivän kuluttua vieroituksesta rehu vaihdettiin Juniori-Pekoni -täysrehuun (1,10 ry/kg ja 11,4 g/ry sulavaa lysiiniä), jota syötettiin kolmen viikon ajan. Sen jälkeen porsaat saivat Pekoni 100 -täysrehua (1,04 ry/kg ja 10,0 g/ry sulavaa lysiiniä) välitykseen saakka.

Lihasikalassa samassa välikasvatuskarsinassa olleet porsaat jaettiin satunnaisesti kahteen vierekkäiseen 10 sian karsinaan, joilla oli yhteinen ruokintakaukalo. Lihasiat punnittiin 4 - 5 viikon kasvatuksen jälkeen rehua vaihdettaessa ja lopussa viikoittain teuraaksi lähettämisen optimoimiseksi (teuraspainotavoite oli $87 \mathrm{~kg}$ ). Lihasikalassa oli liemiruokinta ja alkukasvatuksessa siat saivat Pekoni 100 -täysrehun ja Altia Oyj:n Tähkä-OVR:n (kuiva-aine (KA) 17,7 \pm 0,7 \%, 1,07 ry/kg KA) seosta. Ohravalkuaisrehun osuutta nostettiin neljän ensimmäisen viikon aikana asteittain 6:sta $15 \%$ :iin liemen kuiva-aineesta (seoksessa 1,18 - 1,17 ry/kg KA ja 9,9-9,8 g/ry sulavaa lysiiniä). Lihasikojen loppukasvatuksessa siat saivat Pekoni 80 -täysrehun (1,02 ry/kg ja 8,0 g/ry sulavaa lysiiniä) ja Tähkä-OVR:n seosta, jossa ohravalkuaisrehua oli $15 \%$ liemen kuiva-aineesta (seoksessa 1,15 ry/kg KA ja 8,1 g/ry sulavaa lysiiniä). Seoksiin lisättiin vettä ja liemen kuiva-ainepitoisuuden tavoite oli $27 \%$. Siat ilmoitettiin teuraaksi elopainon ollessa vähintään $105 \mathrm{~kg}$, ja ne teurastettiin seuraavalla viikolla. Loppupaino punnittiin päivä ennen teurastamista. Teurastamossa (HK Agri Oy, Forssa) ruhoista ja sen osista mitattiin lihaprosentti Autofom-laitteistolla.

Aineisto analysoitiin käyttäen SAS ${ }^{8} 9.2$-ohjelmaa. Syntymäpainon ja tuotantotulosten (myöhemmät painot, kasvu ja lihaprosentti) välistä riippuvuutta tarkasteltiin Pearsonin osittaiskorrelaatioiden avulla, jolloin muuttujien välisestä riippuvuudesta poistettiin kasvatuserän, isälinjan, sukupuolen ja syntymäpainon punnitusiän $(0-2 \mathrm{pv})$ vaikutukset. Syntymäpainon vaikutusta sikojen kasvuun ja ruhon laatuun analysoitiin käyttäen sekamallia, jossa oli syntymäpahnueen ja kasvatuserän satunnaiset vaikutukset ja isälinjan ja sukupuolen kiinteät vaikutukset ja näiden yhdysvaikutus, kovariaattina syntymäpainon lineaarinen ja käyräviivainen vaikutus, ja kaikki kiinteiden tekijöiden ja kovariaattien väliset yhdysvaikutukset. Analysoitaessa porsaiden painoja ja kasvua, kovariaattina oli myös emakon imettämien porsaiden lukumäärä. Jos jonkun em. tekijän vaikutus ei ollut tilastollisesti merkitsevä $(P>0,05)$, mallia yksinkertaistettiin jättämällä ko. tekijä mallista pois. Tuloksina esitetään yksinkertaisimmalla mallilla estimoidut regressioyhtälöt porsaan syntymäpainon ja tuotantotulosten välisestä yhteydestä.

\section{Tulokset ja tulosten tarkastelu}

Aineiston 59 pahnueen porsaista 7 \% syntyi kuolleena, mikä on hieman vähemmän kuin Holmin ym. (2004) raportoima 9 \% syntymäkuolleisuus norjanmaatiaisrodun ensipahnueissa. Holmin ym. (2004) noin 6700 pahnueen aineistossa pahnuekokokin oli hieman suurempi (11,46 elävänä ja 1,09 kuolleena syntynyttä) kuin tässä tutkimuksessa (11,3 elävänä ja 0,8 kuolleena syntynyttä), ja syntymäkuolleisuuden ja pahnuekoon välillä on positiivinen yhteys. Havaitsemamme syntymäkuolleisuus on samalla tasolla verrattuna useissa aikaisemmissa tutkimuksissa tehtyihin havaintoihin (Spicer ym. 1986, Canario ym. 2006, Vanderhaegha ym. 2010). Eläinaines on keskeinen porsaiden syntymäkuolleisuuteen vaikuttava tekijä (Canario ym. 2006, Vanderhaegha ym.2010). Canarion ym. (2006) mukaan kuolleena syntyneiden porsaiden todennäköisyys kasvaa kolmannesta porsimakerrasta lähtien ja porsimisen pitkittyminen lisää kuolleena syntyvien porsaiden todennäköisyyttä. Lisäksi kuolleena syntyneitä porsaita on todennäköisemmin pienissä ja suurissa kuin keskikokoisissa pahnueissa. Pahnueen sisällä viimeisinä syntyvillä porsailla on suurin todennäköisyys syntyä kuolleena. Vanderhaeghan ym. (2010) mukaan myös jotkut tuotantotapoihin liittyvät seikat, kuten liian korkea lämpötila porsitusosastossa lisää syntymäkuolleisuuden riskiä. 
Taulukko 1. Porsaiden syntymäpainojen tunnusluvut.

\begin{tabular}{lccccc}
\hline & $\mathrm{N}$ & Keski-arvo & Keskihajonta & Minimi & Maksimi \\
\hline Kaikki porsaat & 655 & 1,73 & 0,40 & 0,5 & 2,9 \\
Syntynyt kuolleena & 45 & 1,78 & 0,38 & 0,7 & 2,9 \\
Kuollut ennen vieroitusta & 49 & 1,43 & 0,44 & 0,6 & 2,8 \\
Kuollut vieroituksen jälkeen & 12 & 1,67 & 0,38 & 0,5 & 2,6 \\
Teurastettu, vaivoja/pieni & 46 & 1,55 & 0,40 & 0,7 & 2,2 \\
Teurastettu, virheetön & 513 & 1,78 & 0,42 & 0,5 & 2,6 \\
\hline
\end{tabular}

Porsaiden syntymäpainoa kuvaavat tunnusluvut on esitetty taulukossa 1. Kuolleena syntyneiden porsaiden syntymäpaino ja sen hajonta olivat keskimäärin samanlaisia kuin elävänä syntyneillä porsailla. Le Cozlerin ym. (2002) mukaan porsaan syntymäpaino tai pahnueen porsaiden syntymäpainojen hajonta eivät vaikuta porsaiden syntymäkuolleisuuteen. Canarion ym. (2006) mukaan, pieni syntymäpaino ja suuri syntymäpainojen hajonta pahnueessa lisäisivät todennäköisyyttä porsaan syntyä kuolleena. Tässä tutkimuksessa ennen vieroitusta kuolleilla porsailla oli pienin syntymäpaino, mikä on yhteneväinen aikaisempien tutkimustulosten kanssa (Quiniou ym. 2002, 2004). Le Dividichin (1999) mukaan porsas on syntyessään pieni, kun sen syntymäpaino on alle 75-80 \% pahnueen keskimääräisestä syntymäpainosta. Porsaita, joiden syntymäpaino oli alle 80 \% pahnueen keskimääräisestä syntymäpainosta, oli eniten ennen vieroitusta kuolleiden porsaiden joukossa ja toiseksi eniten sioissa, joilla oli kasvatusajalta merkintöjä vaivoista tai jotka oli teurastettu pieninä (kuvio 2). Tähän ryhmään luokiteltiin ne siat, joilla oli kasvatusajalta merkintöjä vioista (napatyrät $16 \mathrm{kpl}$, nivustyrä $1 \mathrm{kpl}$ ), sairauksista ja niiden hoidoista, ja jotka lähtivät teuraaksi alle 105 kg elopainossa, ja joiden ruhoista oli teurastuksessa hylätty osia. Fix’n ym. (2010b) mukaan hyvälaatuisten välitysporsaiden teurassikojen todennäköisyys pienenee voimakkaasti, kun porsaan syntymäpaino on pahnueen keskimääräistä syntymäpainoa pienempi.

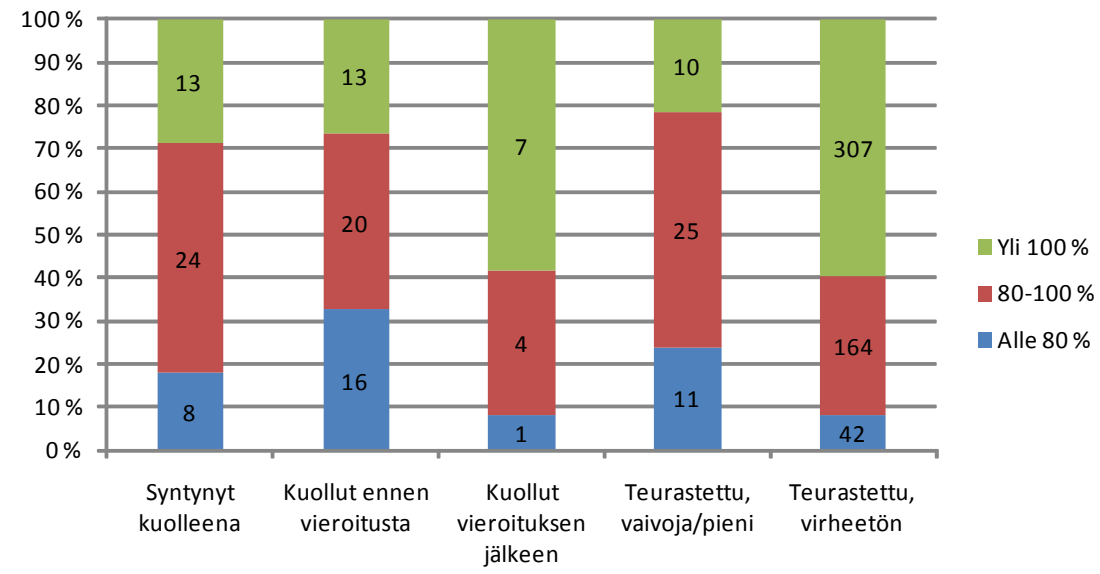

Kuvio 2. Porsaan suhteellisen syntymäpainon (syntymäpaino/pahnueen keskisyntymäpaino × 100) jakauma sikojen menestymistä kuvaavissa ryhmissä.

Taulukossa 2 on esitetty sikojen eri kasvatusvaiheiden painoja ja kasvuja ja teuraslaatua kuvaavat tunnusluvut. Estimoitaessa lineaarisen regression avulla pahnueeseen syntyneiden porsaiden lukumäärän ja syntymäpainon välistä yhteyttä, pahnueen porsaiden keskimääräinen syntymäpaino pieneni 46 g, pienimmän porsaan paino $81 \mathrm{~g}$ ja suurimman porsaan paino $21 \mathrm{~g}$ pahnuekoon kasvaessa porsaalla. Beaulieun ym. (2010) tutkimuksessa porsaiden syntymäpaino pieneni keskimäärin 33 g porsasta kohti. Pahnuekoon kasvaessa syntymäpainojen variaatiokerroin suureni 0,9 \%-yksikköä per porsas, mikä on yhteneväinen aikaisempien tutkimustulosten kanssa (Quesnel ym. 2008). Suurissa pahnueissa havaittavan syntymäpainon pienenemisen syyksi on esitetty tilan ahtautta kohdun sarvissa ja sikiöiden ravintoaineiden saannin rajoittumista (Père ym. 1997, Père ja Etienne 2000). Pèren ja Etiennen (2000) mukaan emakko sopeutuu tiineyteen lisäämällä veren virtausta kohtuun. Kohdun kapasiteetti ei kuitenkaan riitä, kun sarvessa on yli viisi sikiötä. Le Cozlerin ym. (2002) mukaan porsaiden syntymäkuolleisuutta saadaan pienennettyä porsimisten valvomisten avulla. Myös emakon kunto ja tiineysajan ruokinta voivat vaikuttaa porsaiden syntymäpainoon. Rechfeldtin ym. (2011) mukaan ensikon liian niukka tai liian runsas valkuaisruokinta tiineys- 
aikana hidastaa sikiöiden kasvua ja syntymäpainot pienevät.

Enintään $1 \mathrm{~kg}$ painoisena syntyneistä porsaista $37 \%$ kuoli kasvatusaikana, ja näistä suurin osa jo ennen välitysikää. Painoluokissa 1,1 -1,3 kg, 1,4-1,7 kg, 1,8 - 2,0 kg ja yli 2,0 kg elävänä syntyneiden porsaiden kuolleisuus oli 16, 11, 9 ja 3 \%. Myös Quiniou ym. (2002) havaitsivat porsaiden kuolleisuuden pienenevän syntymäpainon kasvaessa. Porsaista 59 siirrettiin ensimmäisten elinpäivien aikana toisen emakon imetettäväksi, koska oman emän nisät eivät olisi riittäneet kaikkien porsaiden imeä yhtä aikaa. Siirretyt porsaat olivat keskimäärin 70 g painavampia kuin oman emän imetettäväksi jääneet porsaat. Kaikki siirretyt porsaat säilyivät hengissä ja kasvoivat hyvin. Siirtojen onnistumista helpotti myös emakoiden porsiminen varsin lyhyen ajan sisällä.

Taulukko 2. Painojen, kasvun ja teuraslaadun tunnusluvut.

\begin{tabular}{lccccc}
\hline Muuttuja & $\mathrm{N}$ & Keskiarvo & Keskihajonta & Minimi & Maksimi \\
\hline Paino, kg & & & & & \\
$\quad$ Vieroitettaessa & 571 & 9,3 & 2,1 & 3,3 & 17,6 \\
Siirrettäessä lihasikalaan & 566 & 37,0 & 7,8 & 13,9 & 60,4 \\
Loppukasvatuksen alussa & 556 & 64,9 & 8,9 & 22,0 & 94,0 \\
Kasvatuksen lopussa & 554 & 114,4 & 5,7 & 83,0 & 137,0 \\
Kasvu, g/pv & & & & & \\
Pahnueaika & 571 & 276 & 62 & 76 & 497 \\
Välikasvatus & 566 & 632 & 136 & 133 & 1007 \\
Lihasikojen alkukasvatus & 556 & 842 & 153 & 217 & 1357 \\
Lihasikojen loppukasvatus & 554 & 1122 & 138 & 439 & 1607 \\
Koko kasvatusaika & 554 & 762 & 59 & 485 & 960 \\
Teurasikä, pv & 554 & 150 & 9 & 131 & 172 \\
Teuraspaino, kg & 550 & 85,3 & 5,0 & 58,5 & 104,3 \\
Lihaprosentti & & & & & \\
Kinkku & 545 & 74,1 & 1,5 & 67,2 & 78,2 \\
Selkä & 545 & 63,2 & 2,4 & 52,1 & 70,0 \\
Kylki & 545 & 58,3 & 2,4 & 48,3 & 64,3 \\
Lapa & 545 & 67,9 & 1,4 & 61,8 & 71,6 \\
Koko ruho & 550 & 60,9 & 1,7 & 53,0 & 65,6 \\
\hline
\end{tabular}

Porsaan syntymäpainon ja kasvun välillä oli positiivinen korrelaatio $(\mathrm{P}<0,001)$ : kasvu pahnueaikana $r=0,46$, välikasvatuksessa $r=0,46$ ja syntymästä välitykseen $r=0,51$. Syntymäpainon ja lihasikojen kasvun ja ruhon lihakkuuden väliset korrelaatiokertoimet olivat pieniä. Syntymäpainon ja kokonaiskasvun tai teurasiän välinen korrelaatio oli 0,38 (P < 0,001). Beaulieun ym. (2010) tutkimuksessa syntymäpainon ja myöhempien painojen välinen korrelaatio pieneni sikojen kasvaessa ja syntymäpainon ja teurasiän välinen korrelaatio oli 0,32 . Emakon imettämien porsaiden lukumäärän ja porsaiden kasvun välinen korrelaatio oli -0,30 (P <0,001) pahnueaikana ja -0,12 (P < 0,01) välikasvatuksessa.

Estimoidut regressioyhtälöt porsaan syntymäpainon yhteydestä myöhempiin painoihin ja kasvuun on esitetty taulukossa 3. Kasvatuserän satunnainen vaikutus ei ollut merkitsevä minkään tutkitun muuttujan kohdalla, joten se jätettiin malleista pois. Syntymäpahnueen satunnainen vaikutus oli merkitsevä, ja se oli mukana kaikkien muuttujien analysoinnissa. Porsaan vieroituspaino ja kasvu ennen vieroitusta suurenivat lineaarisesti syntymäpainon kasvaessa. Syntymäpainon lisäksi imevien porsaiden kasvuun ja vieroituspainoon vaikutti emakon imettämien porsaiden lukumäärä. Kasvu hidastui ja vieroituspaino pieneni imetettävien porsaiden lukumäärän kasvaessa. Syntymäpainon ja välikasvatusajan kasvun välillä havaittiin käyräviivainen yhteys, kuten myös kasvussa syntymästä välitykseen. Kun analysointiin otettiin mukaan vain ongelmitta teurastukseen asti kasvaneet siat, emakon imettämien porsaiden lukumäärä vaikutti myös näiden vaiheiden kasvuun. Sen sijaan sukupuolen ja isälinjojen välillä ei havaittu merkitseviä eroja siinä, miten syntymäpaino vaikutti porsaiden kasvuun. Fix’n ym. (2010a) tutkimuksessa porsaiden syntymäpainon ja myöhemmän kasvun välillä on käyräviivainen yhteys sekä porsaiden välikasvatuksessa että lihasikavaiheessa. Tässä tutkimuksessa porsaan syntymäpainolla ei ollut kuitenkaan merkitsevää vaikutusta lihasikojen kasvuun. Sen sijaan syntymän ja teurastuksen välisen kokonaiskasvun välillä oli positiivinen yhteys ja kokonaiskasvu suurenivat lineaarisesti syntymäpainon kasvaessa.

Syntymäpainolla oli käyräviivainen vaikutus sikojen teurastusikään, ja vaikutus oli erilainen tanskalaisen ja norjalaisen duroc-isälinjan jälkeläisissä. Tanskalaisen durocin jälkeläisillä pienimmät syntymä- 
painot pidensivät teurastusikää voimakkaammin kuin norjalaisen durocin jälkeläisillä (kuvio 4). Teurasiän analysoinnissa oli mukana vain ne siat, jotka painoivat teuraaksi lähetettäessä vähintään 105 kg ja olivat kasvaneet ongelmitta. Hitaimmin kasvaneet siat teurastettiin tavoitetta pienempinä, koska osasto haluttiin saada tyhjäksi neljässä viikossa seuraavaa erää varten. Siat joilla oli kasvatusajalta merkintöjä vioista tai vaivoista ja jotka teurastettiin tavoitetta pienempinä, olivat syntymäpainoltaan keskimäärin $230 \mathrm{~g}$ normaalisti kasvaneita sikoja pienempiä (taulukko1). Syntymäpaino ei vaikuttanut merkitsevästi ruhon tai sen osien (kinkku, selkä, kylki, lapa) lihaprosenttiin, mikä on yhteneväinen Quinioun ym. (2004) raportoimien tulosten kanssa (Quiniou ym. 2004). Fix ym. (2010a) havaitsivat ultraäänellä mitatun selkäsilavan ja selkälihaksen paksuuden suurenevan hieman syntymäpainon kasvaessa.

Taulukko 3. Estimoidut regressioyhtälöt syntymäpainon vaikutuksesta sikojen painoon ja kasvuun.

\begin{tabular}{|c|c|c|c|c|c|c|c|c|c|c|c|c|}
\hline & \multirow[b]{2}{*}{$\mathrm{N}^{\mathrm{a}}$} & \multirow[b]{2}{*}{ Vakio } & \multirow[b]{2}{*}{ SE } & \multicolumn{6}{|c|}{ Syntymäpaino, kg } & \multicolumn{3}{|c|}{ Imetettävien } \\
\hline & & & & Lin. & SE & $\mathrm{P}$ & Kvadr. & SE & $\mathrm{P}$ & $\mathrm{lkm}$ & SE & $\mathrm{P}$ \\
\hline \multirow[t]{2}{*}{ Vieroituspaino, kg } & 571 & 5,62 & 0,71 & 2,80 & 0,19 & $* * *$ & & & & $-0,114$ & 0,049 & $*$ \\
\hline & 506 & 6,56 & 0,74 & 2,54 & 0,20 & $* * *$ & & & & $-0,149$ & 0,050 & $* *$ \\
\hline \multirow[t]{2}{*}{ Välityspaino, kg } & 566 & 12,5 & 3,4 & 19,3 & 3,9 & $* * *$ & $-2,95$ & 1,15 & $*$ & & & \\
\hline & 506 & 19,5 & 4,4 & 19,0 & 4,3 & $* * *$ & $-3,37$ & 1,23 & $* *$ & $-0,445$ & 0,19 & $*$ \\
\hline Kasvu & 571 & 204 & 24 & 65,3 & 6,8 & $* * *$ & & & & $-3,99$ & 1,64 & $*$ \\
\hline pahnueaikana, g/pv & 506 & 241 & 25 & 57,7 & 7,2 & $* * *$ & & & & $-5,50$ & 1,67 & $* *$ \\
\hline Kasvu & 566 & 217 & 67 & 340 & 78 & $* * *$ & $-57,3$ & 22,7 & $*$ & & & \\
\hline välikasvatuksessa, g/pv & 506 & 337 & 86 & 336 & 85 & $* * *$ & $-65,1$ & 24,4 & $* *$ & $-7,50$ & 3,62 & $*$ \\
\hline Kasvu syntymästä & 566 & 179 & 47 & 255 & 55 & $* * *$ & $-41,0$ & 15,9 & $*$ & & & \\
\hline välitykseen, g/pv & 506 & 271 & 60 & 255 & 59 & $* * *$ & $-48,1$ & 17,0 & $* *$ & $-6,08$ & 2,49 & $*$ \\
\hline Kasvu syntymästä & 554 & 638 & 13 & 69,5 & 6,6 & $* * *$ & & & & & & \\
\hline teurastukseen, g/pv & 506 & 677 & 12 & 51,3 & 6,0 & $* * *$ & & & & & & \\
\hline
\end{tabular}

${ }^{\mathrm{a}}$ Suuremmalla havaintomäärän yhtälössä on mukana kaikki tutkimuksessa kasvatetut siat, jotka ovat selvinneet ko. tuotantovaiheeseen. Pienemmässä havaintomäärässä on mukana vain ne siat, jotka ovat kasvaneet ongelmitta teurastukseen saakka ja teurastettu virheettöminä.

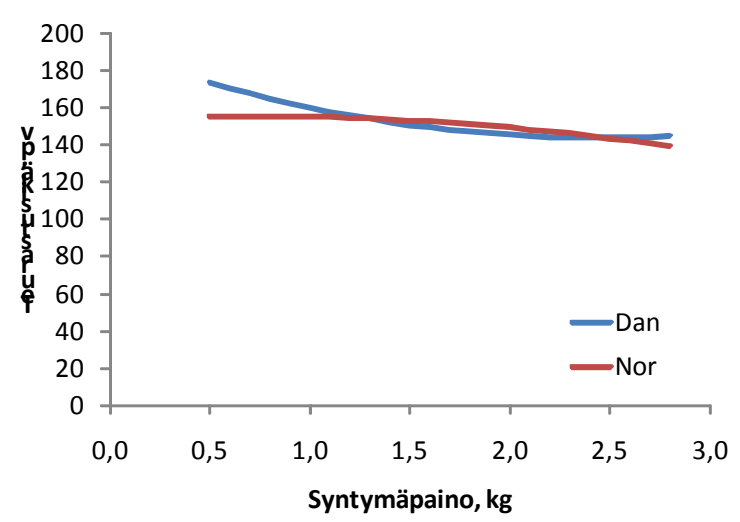

Kuvio 4. Syntymäpainon ja teurasiän välinen yhteys tanskalaisen ja norjalaisen duroc-isälinjojen jälkeläisissä. 


\section{Johtopäätökset}

Porsaan syntymäpainolla on merkitystä porsaan selviytymisen ja kasvun kannalta. Syntymäpainon vaikutus on suurin imetyksen ja välikasvatuksen aikana, mutta se näkyy myös kokonaiskasvussa syntymästä teurastukseen. Elävänä syntyneiden porsaiden kuolleisuus pieneni syntymäpainon kasvaessa. Enintään kilon painoisista porsaista 37 \% menehtyi kasvatuksen aikana. Syntymäpainon vaikuttaa porsaiden kasvuun syntymästä välitykseen, muttei enää lihasikojen kasvuun. Pahnue- ja välikasvatusajan hitaammasta kasvusta johtuen siat saavuttavat tavoiteteuraspainon vanhempina. Syntymäpaino ei kuitenkaan vaikututa ruhojen lihakkuuteen.

\section{Kirjallisuus}

Beaulieu, A.D., Aalhus, J.L., Williams, N.H. \& Patience, J.F. 2010. Impact of piglet birth weight, birth order and litter size on subsequent growth performance, carcass quality, muscle composition and eating quality of pork. Journal of Animal Science 88: 2767-2778.

Canario, L., Cantoni, E., Le Bihan, E., Caritez, J.C., Billon, Y., Bidanel, J.P. \& Foulley, J. L. 2006. Betweenbreed variability of stillbirth and its relationship with sow and piglet characteristics. Journal of NAimal Science 84: 3185 - 3196.

Deen, M.G.H. \& Bilkei, G. 2004. Cross fostering of low-birthweight piglets. Livestock Production Science 90: 279284.

Fix, J.S., Cassady, J.P., Herring, W.O., Holl. J.W., Culbertson, M.S. \& See, M.T. 2010a. Effect of piglet birth weight on body weight, growth, backfat, and longissimus muscle area of commercial market swine. Livestock Science 127: 51-59.

Fix, J.S., Cassady, J.P., Holl. J.W., Herring, W.O., Culbertson, M.S. \& See, M.T. 2010b. Effect of piglet birth weight on survival and quality of commercial market swine. Livestock Science 132: 98 - 106.

Glastonbury, J.R.W. 1977. Preweaning mortality in the pig. Australian Veterinary Journal 53: 282 - 286.

Holm, B., Bakken, M., Vangen, O. \& Rekaya, R. 2004. Genetic analysis of litter size, parturition length, and birth assistance requirements in primiparous sows using a joint linear-treshold anaimal model. Journal of Animal Science 82: 2528 - 2533.

Le Cozler, Y., Guyomarch'h, C., Pichodo, X., Quinio, P.-Y. \& Pellois, H. 2002. Factors associated with stillborn and mummified piglets in high-prolific sows. Animal Reserch 51: $261-268$.

Le Dividich, J. 1999. A review - neonatal and weaner pig: management to reduce variation. Manipulating pig production VII (ed. P.D. Cranwell), pp. 135 - 155. Australasian Pig Science Association, Werribee, VIC, Australia.

Leenhouwers, J.I., van der Lende, T. \& Knol, E.F. 1999. Analysis of stillbirth in different lines of pigs. Livestock Production Science 57: 243-253.

Père, M.C., Dourmad, J.Y. \& Etienne, M. 1997. Effect of number of pig embryos in the uterus on their survival and development and on maternal metabolism. Journal of Animal Science 75: 1337 - 1342.

Père, M.C. \& Etienne, M. 2000. Uterine blood flow in sows: Effects of pregnancy stage and litter size. Reproduction and Nutrition Development 40: 369-382.

Quesnel, H., Brossard, L., Valancogne, A. \& Quiniou, N. 2008. Influence of some sow characteristics on withinlitter variation of piglet birth weight. Animal 2: $1842-1849$.

Quiniou, N., Dagon, J. \& Gaudré, D. 2002. Variation of piglets’ birth weight and consequences on subsequent performance. Livestock Production Science 78: 63-70.

Quiniou, N., Gaudre, D., Pichodo, X. \& Le Cozler, Y. 2004. Caractérisation de líndice de consummation pendant léngraissement selon le pois des porcelets à la naissance. Journées de la Recherce Porcine 36: 403-408.

Rehfeldt, C., Lang, I.S., Görs, S., Henning, U., Kalbe, C., Stabenow, B, Brüssow, K.-P., Pfuhl, R., Bellmann, $O$. \& Nürnberg, G. 2011. Limited and excess dietary protein during gestation affects growth and compositional traits in gilts and impairs offspring faetal growth. Journal of Animal Science 89: 329 - 341.

Schenkel, A.C., Bernardi, M.L., Bortolozzo, F.P. \& Wentz, I. 2010. Body reserve mobilization during lactation in first parity sows and its effect on second litter size. 132: 165-172.

Spicer, E.M., Driesen, S.J., Fahy, V.A., Horton, B.J., Sims, L.D., Jones, R.T., Cutler, R.S. \& Prime, R.W. 1986. Causes of preweaning mortality on a large intensive piggery. Australian Veterinaty Journal 63: 71-75.

Vanderhaeghe, C., Dewulf, J., Ribbens, S., de Kruif, A. \& Maes, D. 2010. A cross-sectional study to collect risk factors associated with stillbirths in pig herds. Animal Reproduction Science 118: 62 - 68. 